\title{
WILLIAM JAMES ON \\ THE COURAGE TO BELIEVE
}




\section{American Philosophy Series}

1. Peirce and Contemporary Thought: Philosophical Inquiries, edited by Kenneth Laine Ketner

2. Classic American Philosophers: Peirce, James, Royce, Santayana, Dewey, Whitehead, edited by Max H. Fisch, second edition Introduction by Nathan Houser

3. John E. Smith, Experience and God, second edition

4. Vincent G. Potter, Peirce's Philosophical Perspectives, edited by Vincent M. Colapietro

5. Philosophy in Experience: American Philosophy in Transition, edited by Richard E. Hart and Douglas R. Anderson

6. Vincent G. Potter, Charles S. Peirce: On Norms and Ideals, second edition Introduction by Stanley M. Harrison

7. Reason, Experience, and God: John E. Smith in Dialogue, edited by Vincent M. Colapietro 


\section{WILLIAM JAMES $\mathrm{ON}$ \\ THE COURAGE TO BELIEVE}

Second Edition

Robert J. O'Connell, S.J.

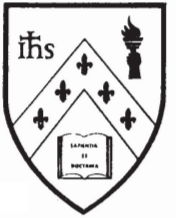

Fordham University Press

New York

1997 
The text of this book is licensed under a Creative Commons Attribution-NonCommercial-NoDerivatives 4.0 International License:

https://creativecommons.org/licenses/by-nc-nd/4.0/.

Open Access edition funded by the National Endowment for the Humanities/ Andrew W. Mellon Foundation Humanities Open Book Program.

\section{तै⿳⺈⿴囗十大 Humanities}

(C) Copyright 1997 by Fordham University Press

First Open Access edition, 2019

To use this book, or parts of this book, in any way not covered by the license, please contact Fordham University Press, Rights \& Permissions, Joseph A. Martino Hall, 45 Columbus Avenue, New York, NY 10023-6917, or copyright@fordham.edu.

$$
\text { LC 97-12135 }
$$

ISBN 0-8232-1727-2 (hardcover)

ISBN 0-8232-1728-0 (paperback)

ISSN 1073-2764

American Philosophy Series No. 8

Vincent M. Colapietro, Editor

Vincent G. Potter (1929-1994), Founding Editor

Visit us online at www.fordhampress.com.

Library of Congress Cataloging-in-Publication Data

O’Connell, Robert J.

William James on the courage to believe / Robert J. O'Connell.[2nd rev. ed.]

p. $\mathrm{cm}$.

Includes bibliographical references and index.

ISBN 0-8232-1727-2. - ISBN 0-8232-1728-0 (pbk.)

1. James, William, 1842-1910. Will to believe. 2. Philosophy.

3. Belief and doubt. I. Title.

B945.J23W536 1997

121'.6-DC21 
To

$$
\begin{gathered}
\text { all my exemplars } \\
\text { of the courage to believe } \\
\text { starting with } \\
\text { my sisters }
\end{gathered}
$$

JANe, MARgaret, Ellen, and MARY

and my brother

JOHN

but going on

and on

and on 
